Rev. Bras. Saúde Prod. Anim., Salvador, v.16, n.2, p.308-316 abr./jun.., 2015 http://www.rbspa.ufba.br

\title{
Antimicrobials resistance patterns and the presence of stx1, stx 2 and eae in Escherichia coli
}

\author{
Padrões de resistência antimicrobianos e da presença de stxl, stx2 e "eae" em \\ "Escherichia coli"
}

\author{
ASSUMPÇÃO, Gustavo Lacerda Homem ${ }^{1}$; CARDOZO, Marita Vendovelli ${ }^{1}$; BERALDO, \\ Lívia Gerbase $^{1}$; MALUTA, Renato Pariz ${ }^{2}$; SILVA, Joviany Talita ${ }^{3}$; AVILA, Fernando \\ Antonio de ${ }^{4}$; McINTOSH, Douglas ${ }^{5}$; RIGOBELO, Everlon $\mathrm{Cid}^{6 *}$
}

\footnotetext{
${ }^{1}$ Universidade Estadual Paulista, Faculdade de Ciências Agrárias e Veterinárias, Programa de Pós-Graduação em Microbiologia Veterinária, Jaboticabal, São Paulo, Brasil.

${ }^{2}$ niversidade Estadual de Campinas, Departamento de Genética, Campinas, São Paulo, Brasil.

${ }^{3}$ Universidade Estadual Paulista, Faculdade de Ciências Agrárias e Veterinárias, Programa de Pós-Graduação em Microbiologia Agropecuária, Jaboticabal, São Paulo, Brasil.

${ }^{4}$ Universidade Estadual Paulista, Faculdade de Ciências Agrárias e Veterinárias, Departamento de Patologia Veterinária, Jaboticabal, São Paulo, Brasil.

${ }^{5}$ Universidade Federal do Rio de Janeiro, Instituto de Veterinária, Departamento de Parasitologia Animal, Seropédica, Rio de Janeiro, Brasil.

${ }^{6}$ Universidade Estadual Paulista, Faculdade de Ciências Agrárias e Veterinárias, Departamento de Produção Vegetal, Jaboticabal, São Paulo, Brasil.

*Endereço para correspondência: everlonnsms@fcav.unesp.br
}

\section{SUMMARY}

The objectives of this study were to investigate whether antimicrobial resistance (AMR) or the presence of resistance genes was associated with the occurrence of the virulence genes, stx 1 , stx 2 and eae. Three virulence genes and 11 AMR phenotypes were examined using polymerase chain reaction (PCR) and antimicrobial susceptibility tests. From 800 samples collected in this study, 561 samples were isolates $E$. coli strains , being: $90(16.0 \%)$ carriers of stx 1,97 $(17.3 \%)$ of $s t x 2$ and $45(8.0 \%)$ of eae genes singly. Thirty seven $(6.6 \%)$ isolates were carriers of stx 1 and stx $2,110(19.6 \%)$ were carriers of $s t x 1$ and eae and $67(11.9 \%)$ were carriers of stx 2 and eae. The most common virulence gene detected was stx 1 followed by stx 2 . The findings showed no relationship between presence of virulence factors and antimicrobial resistance. Also was not found relationship between serogroup and virulence factors.

Keywords: antimicrobial resistance, dairy cow, Escherichia coli, serogroups, STEC

\section{RESUMO}

Objetivou-se com este estudo investigar se a resistência antimicrobiana (RAM) ou a presença de genes de resistência foi associada com a ocorrência dos genes de virulência, stx1, stx2 e eae e os sorogrupos de Escherichia coli isoladas a partir de vacas-vacas leiteiras. Três genes de virulência e 11 fenótipos RAM foram examinados através de PCR e testes de susceptibilidade aos antimicrobianos. Das 800 amostras colhidas neste estudo, 561 amostras foram isoladas cepas de $E$. coli, sendo: $90(16,0 \%)$ portadoras de stx1, 97 $(17,3 \%)$ de stx2 e $45(8,0 \%)$ dos genes eae, separadamente. Trinta e sete $(6,6 \%)$ isolados foram portadores de stx1 e stx2, $110(19,6 \%)$, foram portadores de stxl e eae e $67(11,9 \%)$ foram portadores de stx2 e eae. $\mathrm{O}$ gene de virulência mais comum detectado foi stx 1 seguido por stx2. O sorogrupo predominante entre os isolados portadores de stxl foi O119. Entre as cepas portadoras de stx2, eae e também estirpes com nenhum fator de virulência, o sorogrupo predominante foi O9. O RAM dos isolados, medido fenotipicamente, não foi associado com a presença ou ausência de genes de virulência na população saudável de vaca leiteira-nem a sua 
Rev. Bras. Saúde Prod. Anim., Salvador, v.16, n.2, p.308-316 abr./jun.., 2015 http://www.rbspa.ufba.br ISSN 15199940

ocorrência a qualquer um dos sorogrupos foi associada com genes stx 1 e stx 2 e eae.

Palavras-chave: Escherichia coli, resistência antimicrobiana, sorogrupos, STEC, vaca leiteira

\section{INTRODUCTION}

Currently, Shiga toxigenic Escherichia coli (STEC) strains are the most important emerging groups of foodborne pathogens (BEUTIN et al., 2002). These strains are producer of one or two cytotoxins called Shiga toxins (Stx 1 and Stx2) (PATON \& PATON, 1998). Intimin is another virulence factor responsible for intimate attachment of STEC and it is encoded by the chromosomal gene eae, which is part of a large cluster of virulence genes on a pathogenicity island termed the locus for enterocyte effacement (LEE) (KAPER et al., 1998).

There have been recent reports suggesting that antimicrobial resistance (AMR) levels in STEC is increasing (GALLAND et al., 2001; MENG et al., 1998). The natural evolution of bacteria has been changed by antibiotics use. In specific situations, there is a great probability of association between the presence of virulence factors and antimicrobial resistance (NAGASHINTA et al., 2008). It occurs because both AMR and virulence genes are carried in a similar fashion, may be linked and then co-selected (MARTINEZ \& BAQUEIRO, 2002). When the association between the presence of virulence factors and antimicrobial resistance happens, the antimicrobial use may potentially enhance the selection of bacteria carrying virulence genes, accelerating the spread of virulence genes within bacterial populations (BOERLIN et al., 2005). Contrary, some studies have reported that the acquisition of antimicrobial resistance by some bacterial strains may have a fitness cost which leads to decreased virulence (CALHAU et al., 2013; CLARK et al., 2012).

Gow \& Waldner (2009) demonstrated that antimicrobial resistance is not substantially more likely to be identified in stx positive than in stx-negative E. coli isolates from healthy beef calves. However, there are dearth information in the literature if this association occurs at dairy cow herds and also if there is an association between serogroups of $E$. coli with both stx and eae genes. Therefore, the aims of this study were to investigate if the antimicrobial resistance phenotype was associated with the occurrence of virulence genes, and also investigate if the presence or absence of virulence genes is associated with the serogroups of $E$. coli isolated from dairy cows.

\section{MATERIAL AND METHODS}

Fecal samples were collected in 10 different farms located in São Paulo State, Brazil, from January 2012 to February 2013. From each farm, faeces from the rectum of 80 animals were sampled using sterile swabs. In each farm, the samples were collected in a single day and represented more than $50 \%$ of each population at the time of sampling. Isolates were obtained by directly spreading the samples on MacConkey agar and sorbitol MacConkey agar. After incubation, a minimum of three colonies from each plate were analyzed biochemically (KONEMAN et al., 2001).

Up to two E. coli isolates from each fecal sample were characterized using PCR. To perform PCR, the DNA template was obtained using a thermal cell lysis procedure (KESKIMAKI et al., 2001) and stx1, stx2 and eae were collected using primers and PCR conditions describe by China et al. (1996). 
Antimicrobial disk susceptibility tests were performed using the disk diffusion method recommended by Clinical Laboratory Standard Institute (WATTS et al., 2002). Drug-impregnated disks (CEFAR, São Paulo, Brazil, accessed in 2014) were placed on the surface of Muller-Hinton agar using a disk dispenser.

The serogroup was determined by standard agglutination methods (EDWARDS \& EWING, 1972). The serogroups were either commercially prepared (Probac, Brazil). The following "O" antigens, which include most of the serogroups reported in cow or associated with severe enteric-disease in humans, were used: O5, O6, O8, O9, O20, O26, O55, O75, O86, O91, O101, O146, O149, O153, O157, O158 and O172.

Chi-square and Duncan exact tests were performed for the analysis of associations using software $\mathrm{R}$ version 2.12.0 (http://www.r-project.org/) accessed in
2014. A $\mathrm{P}$ value of $\mathrm{p}<0.01$ was considered to be statistically significant.

\section{RESULTS AND DISCUSSION}

From 800 samples collected of dairy cow herds, it was isolated $561 \mathrm{E}$. coli strains. From these strains, $90(16.0 \%)$ harbored only stx 1, $97(17.3 \%)$ harbored only stx 2 and $45(8.0 \%)$ harbored only eae. Thirty seven $E$. coli strains $(6.6 \%)$ harbored both stx 1 and stx $2 ; 110(19.6 \%)$ harbored stx 1 and eae; and $67(11.9 \%)$ harbored stx2 and eae. Interestingly no strain was harbored to three genes, stx 1 , stx 2 and eae together. The number of $E$. coli strains harboring at least one virulence gene was $446(79.5 \%)$ and the number of strains presenting no gene was 115 $(20.5 \%)$ (Table1).

Table 1. Frequency of Escherichia coli isolates harbored at least one virulence factor for Shiga like toxin (STEC) followed by total of strains harbored of genes for STEC, total of strains without genes for STEC, total of E. coli isolates, total of samples without E. coli and total of samples collected

\begin{tabular}{lcc}
\hline Virulence gene Eschericia coli & Number of isolates & Frequency isolates (\%) \\
\hline stxl & 90 & 16.0 \\
stx2 & 97 & 17.3 \\
eae & 45 & 8.0 \\
stxl+stx2 & 37 & 6.6 \\
stxl+eae & 110 & 19.6 \\
stx2+eae & 67 & 11.9 \\
Number of isolates with genes & 446 & 79.5 \\
Number of isolates without genes & 115 & 20.5 \\
\hline Total of isolates & 561 & 100.0 \\
\hline Total of samples without gene & 239 & 29.9 \\
\hline Total of samples isolates of the total collected & 800 & 70.13 \\
\hline
\end{tabular}

The frequencies of resistance to antimicrobial agents were verified with all E. coli strains carrying a single virulence factor and also with all strains carrying no virulence factor. The $90 \mathrm{E}$. coli isolates that carried $s t x 1$ only showed highest antimicrobial resistance to streptomycin $(85.6 \%)$, followed by kanamycin $(72.2 \%)$ and nalidixic acid $(70.0 \%)$. For this same group, the lowest antimicrobial resistances levels were for 
Rev. Bras. Saúde Prod. Anim., Salvador, v.16, n.2, p.308-316 abr./jun.., 2015 http://www.rbspa.ufba.br

cephalotin (20.0\%), ampicillin (30.0\%) and cefoxitin (35.6\%) (Table2).

For E. coli strains carrying stx 2 only, highest antimicrobial resistance levels were related to streptomycin $(73.2 \%)$, followed by kanamycin and nalidixic acid
$(70.1 \%)$ and the lowest antimicrobial resistance levels were due to cephalotin (14.4\%), ampicillin (29.9\%) and amoxicillin - clavulanic acid (33.0\%) (Table 3).

Table 2. Frequency of resistance to antimicrobial agents among E. coli Shiga like toxin (STEC) isolates harboring stxl from dairy-cow herds $(\mathrm{n}=90)$

\begin{tabular}{lc}
\hline Antimicrobial agent & $\begin{array}{c}\text { Percentage of resistance }-\% \\
\text { (-number of resistant/total number of isolates) }\end{array}$ \\
\hline Ampicillin & $30.0(27 / 90)$ \\
Amoxicillin - clavulanic acid & $40.0(36 / 90)$ \\
Cefoxitin & $35.6(32 / 90)$ \\
Ceftriaxone & $45.6(41 / 90)$ \\
Cephalothin & $20.0(18 / 90)$ \\
Streptomycin & $85.6(77 / 90)$ \\
Kanamycin & $72.2(65 / 90)$ \\
Gentamicin & $55.6(50 / 90)$ \\
Amikacin & $67.8(61 / 90)$ \\
Tetracycline & $38.9(35 / 90)$ \\
Nalidixic acid & $70.0(63 / 90)$ \\
\hline
\end{tabular}

Table 3. Frequency of resistance to antimicrobial agents among E. coli Shiga like toxin (STEC) isolates harboring stx2 from dairy-cow herds $(\mathrm{n}=97)$

\begin{tabular}{lc}
\hline Antimicrobial agent & $\begin{array}{c}\text { Percentage of resistance } \\
\left(\mathrm{n}^{\mathrm{o}} \text { of resistant/total } \mathrm{n}^{\circ} \text { of isolates }\right)\end{array}$ \\
\hline Ampicillin & $29.9(29 / 97)$ \\
Amoxicillin - clavulanic acid & $33.0(32 / 97)$ \\
Cefoxitin & $40.2(39 / 97)$ \\
Ceftriaxone & $46.2(45 / 97)$ \\
Cephalothin & $14.4(14 / 97)$ \\
Streptomycin & $73.2(71 / 97)$ \\
Kanamycin & $70.1(68 / 97)$ \\
Gentamicin & $60.8(59 / 97)$ \\
Amikacin & $67.0(65 / 97)$ \\
Tetracycline & $32.0(31 / 97)$ \\
Nalidixic acid & $70.1(68 / 97)$ \\
\hline
\end{tabular}

For E. coli strains harboring only eae, amikacin $(77.8 \%)$, nalidixic acid $(75.6 \%)$ and streptomycin (73.3\%) were the antimicrobials with the highest resistance levels. For this group, the lowest antimicrobial resistance levels were due to cephalotin $(15.6 \%)$, tetracycline $(24.4 \%)$ and ampicillin (26.7\%) (Table 4).
For the $E$. coli strains with no virulence factor, the highest antimicrobial resistance levels were to streptomycin (78.2\%), followed by kanamycin and nalixic acid (74.1\%), amikacin (64\%). For the same group, the lowest antimicrobial resistance levels were to cephalotin $(17.4 \%)$, 
Rev. Bras. Saúde Prod. Anim., Salvador, v.16, n.2, p.308-316 abr./jun.., 2015 http://www.rbspa.ufba.br

ampicillin (32.9\%) and amoxicillin clavulanic acid (36.0\%) (Table 5).

Among the groups presenting only one virulence factor and the group presenting no virulence factor, there was no statistical difference $(\mathrm{p}>0.01)$ when comparing their antimicrobial resistance patterns.

Table 4. Frequency of resistance to antimicrobial agents among E. coli Shiga like toxin (STEC isolates harboring eae from dairy-cow herds $(n=45)$.

\begin{tabular}{lc}
\hline Antimicrobial agent & $\begin{array}{c}\text { Percentage of resistance } \\
\left(\mathrm{n}^{\circ} \text { of resistant/total } \mathrm{n}^{\circ} \text { of isolates }\right)\end{array}$ \\
\hline Ampicillin & $26.7(12 / 45)$ \\
Amoxicillin - clavulanic acid & $28.9(13 / 45)$ \\
Cefoxitin & $44.4(20 / 45)$ \\
Ceftriaxone & $46.7(21 / 45)$ \\
Cephalothin & $15.6(7 / 45)$ \\
Streptomycin & $73.3(33 / 45)$ \\
kanamycin & $64.4(29 / 45)$ \\
Gentamicin & $48.9(22 / 45)$ \\
Amikacin & $77.8(35 / 45)$ \\
Tetracycline & $24.4(11 / 45)$ \\
Nalidixic acid & $75.6(34 / 45)$ \\
\hline
\end{tabular}

Table 5. Frequency of resistance to antimicrobial agents among ordinary E. coli isolates without stx 1 , stx 2 or eae from dairy-cow herds $(\mathrm{n}=115)$

\begin{tabular}{lc}
\hline Antimicrobial agent & $\begin{array}{c}\text { Percentage of resistance } \\
\left(\mathrm{n}^{\circ} \text { of resistant } / \text { total } \mathrm{n}^{\circ} \text { of isolates }\right)\end{array}$ \\
\hline Ampicillin & $32.9(38 / 115)$ \\
Amoxicillin - clavulanic acid & $36.0(41 / 115)$ \\
Cefoxitin & $45.5(52 / 115)$ \\
Ceftriaxone & $41.2(47 / 115)$ \\
Cephalothin & $17.4(20 / 115)$ \\
Streptomycin & $78.2(90 / 115)$ \\
Kanamycin & $74.1(85 / 115)$ \\
Gentamicin & $68.9(79 / 115)$ \\
Amikacin & $64.0(74 / 115)$ \\
Tetracycline & $38.0(44 / 115)$ \\
Nalidixic acid & $74.1(85 / 115)$ \\
\hline
\end{tabular}

Table 6 shows the frequency of serogroups of E. coli strains that harbour stxl. The serogroups detected were $\mathrm{O} 119$ $(58.0 \%), \mathrm{O} 114 \quad(17 \%), \mathrm{O} 111 \quad(9.0 \%)$, O26, O126, O127, O55 (4.0\%). For E. coli strains that carry stx2, the serogroups and frequencies were O9 $(57.0 \%)$, O8 $(32.0 \%)$, O101 (9.0\%), O20 (2.0\%). For eae+ E. coli strains, the serogroups and frequencies were $\mathrm{O} 9(34.0 \%), \mathrm{O} 8, \mathrm{O} 127$ (22.0\%), O119, O20 (11.0\%) and for $E$. coli strains negative for the virulence genes, the serogroups and frequencies presented were O9 (19.0\%), O119 (16.0\%), O114 (17.0\%), O86 (6.0\%), O125 (5.0\%), O126 (3.0\%), O101, O26, $\mathrm{O} 127, \mathrm{O} 128(2.0 \%)$ and $\mathrm{O} 20(1.0 \%)$. The comparison between the presence of serogroups with the presence or absence of virulence genes did not show correlation. 
Rev. Bras. Saúde Prod. Anim., Salvador, v.16, n.2, p.308-316 abr./jun.., 2015 http://www.rbspa.ufba.br ISSN 15199940

Table 6. Frequency of serogroups of E. coli strains carrying stx1, stx2, eae genes or none of these genes

\begin{tabular}{|c|c|}
\hline \multicolumn{2}{|c|}{ E. coli strains carriers of $\operatorname{stx} 1$ gene $(\mathrm{n}=90)$} \\
\hline Serogroup & Frequency $(\%)$ \\
\hline O119 & 58.0 \\
\hline $\mathrm{O} 114$ & 17.0 \\
\hline O111 & 9.0 \\
\hline $\mathrm{O} 26 \mathrm{O} 126, \mathrm{O} 127, \mathrm{O} 55$ & 4.0 \\
\hline \multicolumn{2}{|c|}{ E. coli strains carriers of $s t x 2$ gene $(\mathrm{n}=97)$} \\
\hline O9 & 57.0 \\
\hline $\mathrm{O} 8$ & 32.0 \\
\hline O101 & 9.0 \\
\hline $\mathrm{O} 20$ & 2.0 \\
\hline \multicolumn{2}{|c|}{ E. coli strains carriers of eae gene $(\mathrm{n}=45)$} \\
\hline O9 & 34.0 \\
\hline O8, 0127 & 22.0 \\
\hline $\mathrm{O} 119, \mathrm{O} 20$ & 11.0 \\
\hline \multicolumn{2}{|c|}{ E. coli strains with none of the virulence genes $(\mathrm{n}=115)$} \\
\hline O9 & 19.0 \\
\hline O119 & 16.0 \\
\hline O114 & 17.0 \\
\hline O86 & 6.0 \\
\hline O125 & 5.0 \\
\hline $\mathrm{O} 126$ & 3.0 \\
\hline $\mathrm{O} 101, \mathrm{O} 26, \mathrm{O} 127, \mathrm{O} 128$ & 2.0 \\
\hline $\mathrm{O} 20$ & 1.0 \\
\hline
\end{tabular}

No statistically significant association was detected between any AMR phenotype and virulence genes and neither between virulence genes and serogroups in this $E$ coli population isolated of dairy-cow herds. The antimicrobial resistance patterns between the isolates carriers of at least one virulence gene or lacking any virulence gene were not different. The results showed that, the presence or absence, and the type of virulence gene did not interfere with the antimicrobial resistance level and also did not favor the selection of resistance genes (Tables1-6). Gow \& Waldner (2009) verified no association between antimicrobial resistance measured phenotypically or the presence of AMR genes and virulence genes (stxl, stx2 and eae) in STEC.

The lack of association between AMR and stx virulence genes may be explained, at least in part, by the requirement for a specific receptor for phage attachment and also the limited amount of DNA incorporated into a phage head and by specific mechanism adopted by bacteriophages to incorporate the bacterial DNA in its genome (SCHWARTS et al., 2006). The mechanisms by which these virulence and resistance genes are transmitted from bacteria to bacteria are determinants for occurrence of these associations (ACHESON et al., 1998; MUNIESA, et al., 2004; NEELY et al., 1998).

Gow \& Waldner (2006) analyzed 106 fecal generic $E$. coli isolates from calves in cow-calf herds and the most common virulence gene detected was stx2 followed by eae. In our study the most common virulence gene detected was stx 1 followed by stx2 (Table 1). Also, in our study, all antimicrobial resistance levels were measured via phenotype rather than genotype. This measurement can lead to some differences. On this account, the presence of unexpressed 
genes would not be measured. However, Gow \& Waldner (2009) measured the antimicrobial resistance level of their isolates phenotypically and also genotypically and did not find difference between both methods.

When the association between antimicrobial resistance and virulence factor occurs, as demonstrated with other genes in previous works (BOERLIN et al., 2005, NAGACHINTA et al., 2008), it becomes more beneficial for the spread of pathogenic bacteria. The association between these factors depends on four main determinants: the bacterial species involved, virulence and resistance mechanisms, the ecological niche, and the host (BECEIRO et al., 2013).

Pereira et al. (2011) analyzed 117 fecal samples from dairy calves divided into two groups, one group received growth promoting antimicrobials (GPA) through milk and another group (NGPA) did not. The results of this study showed that NGPA group had statistically significantly lower levels of antimicrobial resistance for most of the antimicrobials tested than GPA group. Also, there was no association between virulence factors and NGPA or NGA and neither between antimicrobial resistance and virulence factors. Likely, the use of antimicrobials selects some resistance genes, but not virulence genes. Even though, in this and previous studies, there was no association between virulence factors and antimicrobial resistance. This association could take place when the virulence factors and antimicrobial resistance genes are carried in a similar fashion. In this case, it is possible that they could be linked and then co-selected (MARTINEZ \& BAQUEIRO, 2002). Calhau et al. (2013) found a profile of virulence and resistance more prevalent in E. coli. They suggest that these features may be responsible for making them concomitantly virulent and extremely resistant. Nagachinta et al. (2008) found an association between virulence factors and antimicrobial resistance in E. coli strains isolated from dairy cows. However, it is important to point out that these studies have analyzed others genes different than stx 1 , stx2 and eae.

Concerning the presence of serogroups, even though there had been the prevalence of $\mathrm{O} 9$ between $E$. coli strains carriers of stx 2 and eae, there was also the prevalence of the same serogroup between the strains with no virulence factor, suggesting that there was no association between serogroups and virulence factors in this study.

The results did not show relationship between virulence factor and antimicrobial resistance when this association occurs the antimicrobial resistance might be selected through the antimicrobial use and thereby the virulence factor would be selected as well. Probably the mechanism of transfer from one bacterium to another does not permit the association with antimicrobial resistance genes.

\section{REFERENCES}

ACHESON, D.W.; REIDL, J.; ZHANG, X.; KEUSCH, G.T.; MEKALANOS, J.J.; WALDOR, M.K. In vivo transduction with Shiga toxin 1-encoding phage.

Infection and Immunity, v.66, p.44964498, 1998.

BECEIRO, A.; TOMÁS, M.; GERMAN, B.O.U. Antimicrobial resistance and virulence: a successful or deleterious association in the bacterial world.

Clinical Microbiology Reviews, v.26, p.185-230, 2013.

BEUTIN, L.; KAULFUSS, S.; CHEASTY, T.; BRANDENBURG, B.; ZIMMERMAN, S.; GLEIER, K.; WILLSHAW, G.A.; SMITH, H.R. Characteristics and associations with 
Rev. Bras. Saúde Prod. Anim., Salvador, v.16, n.2, p.308-316 abr./jun.., 2015 http://www.rbspa.ufba.br ISSN 15199940

disease of two major subclones of Shiga toxin (verotoxin) producing strains of Escherichia coli (STEC) O157 that are present among isolates from patients in Germany. Diagnostic Microbiology and Infectious Disease, v.44, p.337-346, 2002.

BOERLIN, P.; TRAVIS, R.; GYLES, C.L.; REID-SMITH, R.; JANECKO, N.; LIM, H.; NICHOLSON, V.; MCEWEN, S.A.; FRIENDSHIP, R.; ARCHAMBAULT, M. Antimicrobial Resistance and Virulence Genes of Escherichia coli Isolates from Swine in Ontario. Applied and Environmental Microbiology, v.71, p.6753-6761, 2005.

CALHAU, V.; RIBEIRO, G.; MENDONÇA, N.; SILVA, G.J. Prevalent combination of virulence and plasmidic encoded resistance in ST131. Escherichia coli strain. Virul, v.4, p.726-729, 2013.

CHINA, B.; PERSON, V.; MAINIL, J. Typing of bovine attaching and effacing Escherichia coli by multiplex in vitro amplification of virulence association genes. Applied and Environmental Microbiology, v.62, p.3462-3465, 1996.

CLARK, G.; PASZKIEWICZ, K.; HALE, J.; WESTON, V.; CONSTANTINIDOU, C.; PENN, C.; ACHTMAN, M.; MCNALLY, A.

Genomic analysis uncovers a phenotypically diverse but genetically homogeneous Escherichia coli ST131 clone circulating in unrelated urinary tract infections. Journal of Antimicrobial Chemotherapy, v.67, p.868-77, 2012.

EDWARDS, P.R.; EWING, W.H. Identification of enterobacteriacea. Minneapolis: Burgess Publishing Company, 1972
GALLAND, J.C.; HYATT, D.R.; CRUPPER, S.S.; ACHESON, D.W. Prevalence of antibiotic susceptibility and diversity of Escherichia coli O157:H7 isolates from longitudinal study of beef cattle feedlots. Applied and Environmental Microbiology, v.67, p.1619-1627, 2001.

GOW, S.P.; WALDNER, C.L. Antimicrobial Resistance and Virulence Factors stx 1, stx2, and eae in Generic Escherichia coli isolates from Calves in Western Canadian Cow-Calf Herds. Microbial Drug Resistance, v.15, p.6167, 2009.

KAPER, J.B.; ELLIOT, S.; SPERANDIO, V.; PERNA, N.T.; MAYHEW, G.F.; BLATTNER, F.R. Attaching and effacing intestinal histopathology and the locus of enterocyte effacement. In: KAPER, J.B.; O'BRIEN, A.D. (Eds.). Escherichia coli O157:H7 and Other Shiga-Toxin Producing E. coli Strain. Washington: American Society for Microbiology, 1998.

KESKIMAKI, M.; MATTILA, L.; PELTOLA, H.; SIITONEN, A. EPEC, EAEC and STEC in stool specimens: Prevalence and molecular epidemiology of isolates. Diagnostic Microbiology and Infectious Disease, v.40, p.151-156, 2001.

KONEMAN, E.W.; ALLENS, S.D.; JANDA, W.M.; SCHRECKENBERGER, P.C.; WENN JUNIOR, W.C.

Diagnóstico microbiológico: texto e atlas colorido. Rio de Janeiro: MEDSI, 2001. 1465p.

MARTINEZ, J.; BAQUEIRO, F. Interactions among strategies associated with bacterial infections: pathogenicity, epidemicity and antibiotic resistance.

Clinical Microbiology Reviews, v.15, p.647-679, 2002. 
Rev. Bras. Saúde Prod. Anim., Salvador, v.16, n.2, p.308-316 abr./jun.., 2015 http://www.rbspa.ufba.br

MENG, J.; ZHAO, S.; DOYLE, M.; JOSEPH, S.W. Antibiotic resistance of Escherichia coli $\mathrm{O} 157: \mathrm{H} 7$ and non-O157 strains isolated from humans, cattle, sheep, and food in Spain. Research in Microbiology, v.156, p.793-806, 1988.

MUNIESA, M.; BLANCO, J.E.; SIMON, M. de; SERRA-MORENO, R.; BLANCH, A.R.; JOFRE, J. Diversity of stx2 converting bacteriophages induced from Shiga-toxin-producing Escherichia coli strains isolated from cattle.

Microbiology, v.150, p.2959-2971, 2004.

NAGACHINTA, S.; CHEN, J. Transfer of class1 integron-mediated antibiotic resistance genes from Shiga toxinproducing Escherichia coli to a susceptible $E$. coli K-12 strain in storm water and bovine feces. Applied and Environmental Microbiology, v.74, p.5063-5067, 2008.

NEELY, M.; FRIEDMAN, N. Functional and genetic analysis of regulatory regions of coliphage H-19B: location of Shigatoxin and lysis genes suggest a role of phage functions in toxin release.

Molecular Microbiology, v.28, p.12551267, 1998.

PATON, J.C.; PATON, A.W.

Pathogenesis and diagnosis of Shiga toxin producing Escherichia coli infections. Clinical Microbiology Reviews, v.11, p.450-479, 1998.

PEREIRA, R.V.V.; SANTOS, T.M.A.; BICALHO, M.L.; CAIXETA, L.S.; MACHADO, V.S.; BICALHO, R.C. Antimicrobial resistance and prevalence of virulence factor genes in fecal Escherichia coli of Holstein calves fed milk with and without antimicrobials.

Journal of Dairy Science, v.94, p.45564565, 2011.
SCHWARTZ, S.; CLOECKAERT, A.; ROBERTS, M.C. Mechanisms and spread of bacterial resistance to antimicrobial agents. In: AARESTRUP, F.M. (Ed.). Antimicrobial resistance in bacteria of animal origin. Washington, D.C.: ASM Press, 2006.

WATTS, J.L.; SHRYOCK, T.R.; APLEY, M.; BADE, D.J.; BROWN, S.D.; GRAY, J.T.; HEINE, H.; HUNTER, R.P.; MEVIUS, D.J.; PEPICH, M.G.; SILLEY, P.; ZURENKO, G.E. Performance standards for antimicrobial disk and dilution susceptibility test for bacteria isolated from animals approved Standard. Wayne, PA: National Committee For Clinical Laboratory, 2002.

Data de recebimento: 10/07/2014

Data de aprovação: 18/06/2015 